\title{
DAMPAK PSIKOLOGI BELAJAR DALAM PEMBELAJARAN AKTIF BAGI PESERTA DIDIK MADRASAH IBTIDAIYAH
}

\author{
Anas Rohman \\ Fakultas Agama Islam \\ Universitas Wahid Hasyim Semarang \\ rohman_anas@yahoo.com
}

\begin{abstract}
Abstrak
Psikologi belajar memahami aspek psikis bagaimana peserta didik madrasah ibtidaiyah melakukan aktifitas belajar secara nyaman, diminati dan termotivasi dalam proses pembelajaran aktif. Madrasah Ibtidaiyah merupakan lembaga pendidikan yang mempunyai kontribusi besar dalam mempersiapkan generasi yang unggul dan berkarakter, anak usia tersebut merupakan masa keemasan dalam pembentukan kepribadiannya. Kajian ini menggunakan Metode Participatory Action Research (PAR) melibatkan Guru, peserta didik dan Madrasah Ibtidaiyah. Hasil Kajian 1. Pembelajaran aktif merupakan upaya penting untuk diterapkan di Madrasah Ibtidaiyah.2. Ada kaitan bagaimana proses pembelajaran di kelas tidak hanya menekankan aspek koknitif, afektif dan psikomotorik namun juga melibatkan aspek psikologi belajar sehingga proses pembelajaran menjadi menyenangkan, menggairahkan dan memberdayakan peserta didik.3 Pembelajaran aktif di Madrasah Ibtidaiyah memberikan dampak psikologi belajar yang sangat baik.
\end{abstract}

Kata Kunci :Psikologi Belajar, Pembelajaran Aktif

\begin{abstract}
Learning psychology understand that every students in actualize their whole learning activities there are relations with their motive, interest and seriousness will push someone success in study. MI is an educational institution which has big contribution in preparing exellent generation and good character. Children in that age is in their golden period in shaping their personality. This study use Parcipatory Action Research (PAK) Method, involving teachers, students, and MI. The results of this study: 1) Active Learning is important effort to be applied in MI. 2) There are relation on how the learning process in class not only emphasize on cognitive, affective and psychomotor aspects but also involving learning psychology aspect so that learning process become fun, exciting and empowering students. Active learning in MI give good psychological effect.
\end{abstract}

Keywords: psychological aspects, active learning 


\section{A. PENDAhuluan}

Undang-Undang tentang Sistem Pendidikan Nasional No.20 tahun 2003 dalam ketentuan umum pasal 1 ayat 20 dijelaskan bahwa Pembelajaran merupakan sebuah proses interaksi peserta didik dengan pendidik dan sumber belajar di suatu lingkungan sekolah. ${ }^{1}$ Pembelajaran aktif adalah upaya bagaimana suatu interaksi belajar mengajar tidak hanya bisa diterima, dihayati dan dilaksanakan akan tetapi adanya unsur motif kesenangan dalam proses belajarnya sehingga terjadi timbal balik dinamika yang saling melengkapi yaitu berupa keaktifan peserta didik di dalam ruang sekolah.

Salah satu komponen yang sangat menentukan dalam pencapaian tujuan pembelajaran adalah Pendidik. Pendidik menurut UU No. 14 tahun 2005 ialah pendidik profesional dengan tugas utama mendidik, mengajar, membimbing, mengarahkan, melatih, menilai, dan mengevaluasi peserta didik pada pendidikan anak usia dini jalur pendidikan formal, pendidikan dasar, dan pendidikan menengah." ${ }^{2}$

Pencapaian tujuan pembelajaran di kelas sangat dipengaruhi oleh penerapan strategi atau metode pembelajaran aktif. Menurut Soegeng pembelajaran aktif adalah kegiatan-kegiatan pembelajaran yang melibatkan para pelajar dalam melakukan suatu hal dan memikirkan apa yang sedang mereka lakukan. Pembelajaran aktif itu diturunkan dari dua asumsi dasar yaitu (1) bahwa belajar pada dasarnya adalah proses yang aktif, dan (2) bahwa orang yang berbeda, belajar dalam cara yang berbeda pula. Sementara menurut pembelajaran PAIKEM adalah singkatan dari Pembelajaran Aktif, Inovatif, Kreatif, Efektif, dan Menyenangkan. Aktif dimaksudkan bahwa dalam proses pembelajaran Pendidik

\footnotetext{
${ }^{1}$ Undang-Undang Nomor 20 Tahun 2003, Tentang Sistem Pendidikan Nasional, Jakarta: Depdik.

${ }^{2}$ Undang-Undang Nomor 14 Tahun 2005, Tentang Guru dan Dosen, Jakarta: Depdiknas.
}

52 MAGISTRA - Volume 10 Nomor 1 Juni 2019 
harus menciptakan suasana sedemikian rupa sehingga siswa aktif bertanya, mempertanyakan, dan mengemukakan gagasan. ${ }^{3}$

Pemahaman Psikologi oleh Pendidik terhadap peserta didik dalam proses pembelajaran aktif hendaknya menjadi fokus yang tidak boleh diabaikan mengingat keaktifan belajar peserta didik ada pengaruhnya dengan kemauan, minat dan motivasi sehingga merupakan hal yang menjadikan penentu keberhasilan seorang pendidik ketika mengajar. Pendidik tidak hanya mengajar namun dalam prosesnya melibatkan para peserta didiknya lebih berperan aktif yaitu mengoptimalkan keseluruhan potensi yang dimiliki peserta didik baik fisik maupun psikis sehingga dapat berkembang secara optimal.

Psikologi adalah ilmu yang mempelajari perilaku, ${ }^{4}$ tanpa melihat perkembangan secara psikologis dan melibatkan peran aktif siswa dalam proses pembelajaran maka tujuan pembelajaran yang dinginkan sulit tercapai sehingga pemahaman para pendidik dalam pemebelajaran aktif perlu ditingkatkan terutama menyangkut aspek mental yang menkonstruksi aktifitas yang membangun peserta didik. Kondisi yanga ada di lapangan masih dijumpai proses pembelajaran hanya sekedar monoton di mana pendidik hanya menjadi sumber utama dan hanya sekedar menekankan aspek kognitif dan mengabaiakan aspek psikologi belajar yang menyenangkan dan memberdayakan peserta didik. Maka fokus dalam kajian ini adalah melihat dampak psikologi belajar dari sebuah penerapan pelaksanaan pembelajaran aktif di Madrasah Ibtidaiyah dengan mengupayakan aspek psikologi masuk di dalamnya sehingga tujuan pendidikan nasional yaitu mencerdaskan kehidupan bangsa dan mengembangkan manusia Indonesia seutuhnya dapat tercapai.

${ }^{3}$ Soegeng Ysh., A.Y, Pengembangan Sistem Pembelajaran, Semarang: IKIP PGRI Semarang Press, 2012, hlm. 4.

${ }^{4}$ Nyayu Khodijah, Psikologi Belajar, Rafah Press: Palembang, 2006, hlm.2

53 MAGISTRA - Volume 10 Nomor 1 Juni 2019 


\section{B. METODE PENELITIAN}

Penelitian ini menggunkan metode Participatory Action Research (PAR) yaitu penelitian yang melibatkan secara aktif semua pihak-pihak yang relevan (stakeholder) dalam mengkaji tindakan yang sedang berlangsung di mana pengalaman mereka sendiri sebagai persoalan dalam rangka melakukan perubahan dan perbaikan ke arah yang lebih baik dalam melihat dampak psikologis dalam pembelajaran aktif peserta didik di Madrasah Ibtidaiyah. Penelitian tersebut harus menggali refleksi kritis terhadap konteks sejarah, politik, budaya, ekonomi, geografis, dan konteks lain yang terkait. ${ }^{5}$ Participatory Action Research (PAR) merupakan kombinasi penelitian sosial, kerja pendidikan, dan aksi politik menggunakan konsep penelitian partisipatif dalam konteks metodologi materialis historis yang didefinisikan oleh Kasam sebagai penelitian yang disusun melalui interaksi demokratis antara peneliti dan kelas rakyat yang tertindas. $^{6}$

Pendekatan Participatory Action Research (PAR) adalah penelitian yang melibatkan semua pihak yang relevan dalam meneliti secara aktif secara bersamasama, tindakan saat ini (yang mereka alami sebagai masalah) dalam rangka untuk mengubah dan memperbaikinya. Mereka melakukan hal ini dengan merenungkan secara kritis historis. ${ }^{7}$ Penelitian Tindakan Partisipasi (Participation Action Research) dapat dilakukan oleh guru yang relevan dengan kurikulum saat ini, yang mengampu mata pelajaran di kelas itu sendiri melalui refleksi diri dengan tujuan untuk memperbaiki kinerjanya sebagai guru, sehingga hasil belajar siswa meningkat. ${ }^{8}$

\footnotetext{
${ }^{5}$ Agus Afandi, dkk, Modul Participatory Action Reseacrh (PAR), IAIN Sunan Ampel Surabaya: Lembaga Pengabdian Masyarakat (LPM) 2013, hlm 41.

${ }^{6}$ Mansour Fakih, Menggeser konsepsi gender dan transformasi social, Yogyakarta: Pustaka Pelajar, 2007, hlm 28.

${ }^{7}$ P. Reason,. and H. Bradbury, The Sage Handbook of Action Research: Participative Inquiry and Practice, California: Sage, 2008, hlm 1.

${ }^{8}$ Wardhani \& Kuswaya Wihardit, Penelitian Tindakan Kelas, Jakarta: Universitas Terbuka, 2007, hlm 14 .
} 
Penelitian tindakan ini melibatkan Guru Madrasah Ibtidaiyah. Partisipasi merupakan perpaduan bahwa peneliti menekankan kegiatannya pada keterlibatan pihak lain di luar peneliti, khususnya masyarakat luas yang tertarik dengan kegiatan penelitian yang dilakukan oleh peneliti. ${ }^{9}$ Penelitian Tindakan Partisipasi (Participation Action Research) dapat dilakukan oleh guru dalam menyusun Lembar Kerja Siswa yang relevan dengan kurikulum saat ini, yang mengampu mata pelajaran di kelas itu sendiri melalui refleksi diri dengan tujuan untuk memperbaiki kinerjanya sebagai guru, sehingga hasil belajar siswa meningkat. ${ }^{10}$

Penelitian tindakan dapat dilakukan baik secara grup ataupun individual dengan harapan pengalaman mereka dapat ditiru atau diakses untuk memperbaiki kualitas kerja orang lain. Secara praktis penelitian ini pada umumnya sangat cocok untuk meningkatkan kualitas subjek yang hendak diteliti. Subjek penelitian tindakan ini dapat berupa kelas maupun sekelompok orang yang bekerja di industri atau lembaga sosial lain yang berusaha meningkatkan kualitas kinerja. ${ }^{11}$ Adapun bentuk penelitiannya termasuk penelitian yang didasarkan pada pendekatan kualitatif menekankan pada makna, penalaran, definisi suatu situasi tertentu dan dalam konteks tertentu, lebih banyak meneliti. Jadi dalam penelitian ini pendekatan dan jenis yang digunakan adalah Participation Action Research (PAR) yang melibatkan peserta didik dan Guru Madrasah Ibtidaiyah di Semarang.

Subjek penelitian dalam penelitian ini adalah Guru Madrasah Ibtidaiyah Semarang. Adapun metode pengumpulan data menggunakan metode observasi, metode wawancara dan dokumentasi. Metode observasi digunakan untuk mengadakan pengamatan kerja guru memahami aspek psikologi belajar dalam pembelajaran aktif peserta didik Madrasah Ibtidaiyah di Semarang. Metode

${ }^{9}$ Suharsimi Arikunto, Prosedur Penelitian, Yogyakarta: Aditya Media, 2010, hlm. 38

${ }^{10}$ Wardhani \& Kuswaya Wihardit, Penelitian Tindakan Kelas....hlm 14.

${ }^{11}$ Andi Prastowo, Memahami Metode-Metode Penelitian, Yogyakarta: ArRuzz Media, 2011, hlm 225-226 
wawancara dilakukan dengan menggunakan wawancara tidak terstruktur, yaitu komunikasi bebas di mana peneliti tidak menggunakan pedoman wawancara yang telah tersusun secara sistematis dan lengkap untuk pengumpulan datanya. Pedoman wawancara yang digunakan hanya berupa pokok-pokok permasalahan yang akan ditanyakan. Pedoman wawancara ini dilakukan untuk menghindari kemungkinan melupakan beberapa persoalan yang relevan serta sebagai bimbingan secara mendasar tentang apa yang diungkapkan. Wawancara dilakukan kepada peserta didik dan Guru Madrasah Ibtidaiyah di Semarang.

Metode dokumentasi dilakukan dengan mencari data mengenai hal-hal atau variabel berupa catatan, transkip, buku, surat kabar, prasasti, notulen rapat, agenda dan sebagainya. Pengumpulan data melalui metode ini dilakukan dengan cara mengumpulkan dokumen-dokumen Guru Madrasah Ibtidaiyah di Semarang, kemudian diamati oleh peneliti. Selain itu yang dilakukan peneliti adalah ikut serta mendampingi, memfasilitasi serta tergabung di dalam panitia dalam kegiatan ini, dan bersama-sama membantu guru dalam kegiatan. Di awal pertemuan pelaksanaan kegiatan dilakukan pre tes individu dengan tujuan untuk mengetahui seberapa besar pemahaman, pengetahuan guru tentang dampak psikologi belajar dalam pembelajaran aktif peserta didik. Dalam pelaksanaan kegiatan yang dilakukan selalu mengacu pada rancangan tindakan yang telah dibuat bersama-sama panitia. Pengamatan dalam tahapan ini penulis mengamati dan ikut berpartisipasi secara penuh proses kegiatan untuk mendapatkan data mengenai tindakan yang dilakukan narasumber, panitia, Guru Madrasah Ibtidaiyah dalam kegiatan setelah didapatkan kekurangan dalam proses kegiatan maka peneliti dan guru melakukan upaya perbaikan sebagai acuan untuk pelaksanaan pada kegiatan selanjutnya. 


\section{HASIL DAN PEMBAHASAN}

\section{Pengertian Psikologi Belajar}

Psikologi belajar terdiri dari dua kata yaitu psikologi dan belajar. Kedua kata ini masing-masing memiliki pengertian yang berbeda. Menurut bahasa Psikologi berasal dari bahasa Yunani yaitu kata psyhe =jiwa, logos = ilmu. ${ }^{12}$ Menurut Branca dalam bukunya psychology the science of behavior, psikologi adalah ilmu yang mempelajari perilaku. ${ }^{13}$ Psikologi secara umum mempelajari gejala-gejala kejiwaan manusia yang berkaitan dengan kognisi, emosi, dan konasi. Gejala tersebut secara umum memiliki ciri-ciri yang hampir sama pada diri manusia dewasa, normal, dan beradab. Dengan demikian ketiga gejala pokok tersebut dapat diamati melalui sikap dan perilaku manusia. Sehingga terkadang ada diantara pernyataan dalam tingkah laku yang tampak itu merupakan gejala kombinasi, sehingga para ahli psikologi menambahnya menjadi empat gejala utama yang dipelajari psikologi, yaitu kognisi, emosi, kognisi dan gejala yang saling melengkapi. Adapun yang termasuk gejala kolaborasi ini seperti intelegensi, kelelahan maupun sugesti. ${ }^{14}$

Psikologi juga mengkaji gejala-gejala jiwa yang berhubungan dengan tingkah laku. ${ }^{15}$ Perkembangan dalam arti belajar di sini dipahami sebagai "perubahan" yang relatif permanen pada aspek psikologi. Individu yang berubah karena gangguan jiwa, kesurupan, atau cedera bukanlah termasuk kategori belajar, walaupun mempengaruhi mentalnya untuk sementara. ${ }^{16}$ Menurut Oemar Hamalik, belajar merupakan perubahan tingkah laku yang

\footnotetext{
${ }^{12}$ Rohmalina Wahab, Psikologi Agama, Grafika Telindo: Palembang, 2010, hlm.1

${ }^{13}$ Nyayu Khodijah, Psikologi Belajar, Rafah Press: Palembang, 2006, hlm.2

${ }^{14}$ Jalaluddin, Psikologi Agama, Raja Grafindo Persada: Jakarta, 2010, hlm.7

${ }^{15}$ Ramayulis, Psikologi Agama, Kalam Mulia: Jakarta 2007, hlm.5

${ }^{16}$ Saiful Bahri Djamarah, Psikologi Belajar, Rineka Cipta: Jakarta, 2008, hlm 2
} 
relatif mantap berkat latihan dan pengalaman. ${ }^{17}$ Senada dengan Hintzman, belajar merupakan suatu perubahan yang terjadi dalam struktur diri organisme manusia, dan binatang disebabkan oleh pengalaman yang dapat mempengaruhi tingkah laku orgnisme tersebut. ${ }^{18}$ Dari uraian di atas dapat disimpulkan bahwa belajar sebuah aktivitas jiwa dan raga, menuju perubahan yang relatif permanen pada aspek psikologi yang berkaitan dengan pengetahuan, perasaan, dan keterampilan. Pada hakikatnya belajar mendorong perubahan ke arah positif dan merupakan proses pentransferan nilai berkat latihan dan pengalaman.

Berdasarkan pengertian psikologi dan belajar di atas dapat disimpulkan bahwa psikologi belajar adalah sebuah disiplin ilmu yang mempelajari tentang perilaku dan masalah-masalah dalam belajar serta teori-teori psikologi mengenai belajar, terutama bagaimana cara belajar atau melakukan pembelajaran perubahan ke arah positif yang bersifat relatif permanen mengarah aspek psikologi yang berkaitan dengan pengetahuan, perasaan, dan keterampilan.

\section{Tujuan Psikologi Belajar}

Menurut Wahab, psikologi memiliki tujuan yang sama ataupun titik temu yaitu: pada perubahan tingkah laku, yang mana pendidikan merubah perilaku manusia dari satu taraf perkembangan kepada taraf perkembangan berikutnya dan hal ini seiring dengan kajian psikologi pendidikan yang berkaitan dengan bagaimana upaya seseorang pendidik mempersiapkan diri guna memberikan perilaku pendidikan dan pembelajaran yang efesien dan efektif. Menurut Abu Ahmadi, psikologi bertujuan untuk memberi

${ }^{17}$ Oemar Hamalik, Perencanaan Pengajaran Melalui Pendekatan Sistem, Bumi Aksara: Jakarta, 2002, hlm 154

${ }^{18}$ Muhibbin Syah, Psikologi Belajar, Rajawali Grafindo Persada: Jakarta, 2010, hlm 65 
kesenangan dan kebahagiaan hidup manusia, dan orang yang ingin sukses dalam segala-galanya harus mengetahui dasar-dasar dari ilmu jiwa. ${ }^{19}$

Menurut Dalyono, tujuan dari belajar antara lain: mengadakan perubahan dalam diri (kebiasaan buruk menjadi baik, sikap dari negatif menjadi positif), dapat memiliki keterampilan, serta menambah pengetahuan dalam berbagai bidang ilmu. ${ }^{20}$

Tujuan mempelajari psikologi belajar yaitu agar dapat mengetahui tentang bagaimana proses belajar itu terjadi dan faktor-faktor apa yang mempengaruhi keberhasilannya merupakan hal yang penting dimiliki oleh semua orang, terutama bagi para pendidik dan calon pendidik, diharapkan pengetahuan tersebut dapat membantu para pendidik dalam melaksanakan tugasnya sehingga dapat meningkatkan hasil belajar anak didik secara maksimal. $^{21}$

Dari beberapa pengertian diatas dapat ditarik simpulan bahwa tujuan psikologi belajar mempersiapkan diri guna memberikan perilaku pendidikan dan pembelajaran yang efesien dan efektif mengadakan perubahan dalam diri yang positif memiliki keterampilan, serta menambah pengetahuan dalam berbagai bidang ilmu secara menyenangkan dan membahagiakan.

\section{Pengertian Pembelajaran Aktif}

Menurut Dalvin pembelajaran aktif adalah "belajar yang memperbanyak aktivitas siswa dalam mengakses berbagai informasi dari berbagai sumber, untuk dibahas dalam proses pembelajaran dalam kelas, sehingga memperoleh berbagai pengalaman yang tidak saja menambah pengetahuan, tapi juga kemampuan analisis dan $\operatorname{sintesis}^{22}$.

\footnotetext{
${ }^{19}$ Ria Triana Primasari, Rohmalina Wahab, Elhefni, Kecerdasan Emosional dan Belajar, Palembang: Grafiko Telindo Press, 2012, hlm 55.

${ }^{20}$ Rohmalina Wahab, Psikologi Belajar, Palembang: Grafiko Telindo Press, 2014, hlm 1-2

${ }^{21}$ Muhibbin Syah, Psikologi Belajar, Jakarta: Rajawali Pers, 2013, hlm 67.

${ }^{22}$ Dalvin.Upaya Meningkatkan Keaktifan Belajar Siswa dalam Pembelajaran Agama dengan Menggunakan Metode Belajar Aktif Tipe Quiz Team, Jurnal Guru, 2006, hlm 42
} 
Pembelajaran Aktif dijelaskan bahwa dalam proses pembelajaran Pendidik harus menciptakan suasana sedemikian rupa sehingga siswa aktif bertanya, mempertanyakan, dan mengemukakan gagasan. Belajar memang merupakan suatu proses aktif dari si pembelajar dalam membangun pengetahuannya, bukan proses pasif yang hanya menerima kucuran ceramah pendidik tentang pengetahuan. Jika pembelajaran tidak memberikan kesempatan kepada siswa untuk berperan aktif, maka pembelajaran tersebut bertentangan dengan hakikat belajar. Peran aktif dari siswa sangat penting dalam rangka pembentukan generasi yang kreatif, yang mampu menghasilkan sesuatu untuk kepentingan dirinya dan orang lain. Pengembang pembelajaran ini beranggapan bahwa belajar merupakan proses aktif merangkai pengalaman untuk memperoleh pemahaman baru. Siswa aktif terlibat di dalam proses belajar mengkonstruksi sendiri pemahamannya. Teori belajar konstruktivisme merupakan titik berangkat pembelajaran ini.

Pembelajaran aktif merupakan pendekatan mengajar (approach to teaching) yang digunakan bersama metode tertentu dan berbagai media pengajaran yang disertai dengan penataan lingkungan sedemikian rupa agar proses pembelajaran menjadi aktif, dengan demikian para siswa merasa tertarik dan mudah menyerap pengetahuan dan keterampilan yang diajarkan. selain itu, pembelajaran aktif juga memungkinkan siswa melakukan kegiatan yang beragam untuk mengembangkan sikap, pemahaman, dan keterampilannya sendiri dalam arti tidak semata-mata "disuapi" pendidik. ${ }^{23}$

Dapat disimpulkan bahwa Pembelajaran aktif merupakan aktivitas siswa dalam mengakses berbagai informasi dari berbagai sumber, untuk dibahas dalam proses pembelajaran dalam kelas melalui pendekatan mengajar (approach to teaching) yang digunakan bersama metode tertentu dan berbagai media pengajaran yang disertai dengan penataan lingkungan sedemikian rupa

${ }^{23}$ Syaiful Sagala, Konsep dan Makna Pembelajaran, Bandung; Alfabeta, 2003, hlm 150

60 MAGISTRA - Volume 10 Nomor 1 Juni 2019 
agar proses pembelajaran menjadi aktif yang memungkinkan siswa melakukan kegiatan beragam untuk mengembangkan sikap, pemahaman, dan keterampilannya serta menciptakan suasana sedemikian rupa sehingga siswa aktif bertanya, mempertanyakan, dan mengemukakan gagasan dan merangkai pengalaman untuk memperoleh pemahaman baru.

\section{Fungsi dan Keuntungan Pembelajaran Aktif}

Fungsi pembelajaran aktif membekali peserta didik dengan kecakapan (life skill atau life competency) yang sesuai dengan lingkungan hidup dan kebutuhan peserta didik, misalnya pemecahan masalah secara reflektif sangat penting dalam kegiatan belajar yang dilakukan melalui kerjasama secara demokratis. ${ }^{24}$ Mengembangkan wawasan berpikir secara terbuka dan obyektif, menumbuhkan suasana demokratis dan mengembangkan sikap tenggang rasa terhadap berbagai perbedaan pandangan.

Ada beberapa alasan menggunakan pembelajaran aktif yaitu:(1) memiliki pengaruh yang kuat pada pembelajaran,(2) strategi-strategi pengembangan pembelajaran aktif lebih mampu meningkatkan ketrampilan berfikir para pelajar daripada peningkatan penguasaan isi,(3) melibatkan para pelajar dalam tugas-tugas berpikir tingkat lebih tinggi seperti analisis, sintesis dan evaluasi, dan (4) berbagai gaya belajar dapat dilayani dengan sebaikbaiknya dengan melibatkan para pelajar dalam kegiatan-kegiatan belajar aktif.

Keuntungan penggunaan pembelajaran aktif, yaitu: (1) para pelajar yang aktif menggunakan pengetahuan utama mereka dalam membentuk pemahaman dari isi materi pembelajaran, (2) para pelajar yang aktif berfikir secara kritis dan menciptakan pengembangan mereka sendiri, (3) para pelajar yang aktif terlibat secara kognitif, dan (4) para pelajar yang aktif menerapkan suatu strategi membaca dan belajar lingkup yang luas. ${ }^{25}$ Jadi pembelajaran

\footnotetext{
${ }^{24}$ Mulyani Sumantri, Strategi Belajar Mengajar, Bandung: Maulana, 2001, hlm 114.

${ }^{25}$ Soegeng Ysh., A.Y, Pengembangan Sistem Pembelajaran, Semarang, IKIP PGRI Semarang
} Press, 2012, hlm 4. 
aktif menerapkan suatu strategi dalam membekali peserta didik dengan kecakapan (life skill atau life competency) yang sesuai dengan lingkungan hidup dan kebutuhan peserta didik, dalam mengembangkan wawasan berpikir secara terbuka dan obyektif.

\section{Prinsip pembelajaran aktif}

1. Pembelajaran aktif dilihat prosesnya ${ }^{26}$

Proses pembelajaran aktif berbentuk arahan, pembelajaran dilakukan secara interaktif dan lebih memberikan keleluasaan kepada siswanya untuk dapat mengetahui apakah siswanya memahami apa yang disampaikan.

2. Pembelajaran aktif dari segi sifatnya.

3. Pembelajaran aktif bersifat langsung yaitu memberikan pertanyaanpertanyaan secara lisan pada saat pembelajaran berlangsung. Ini bertujuan untuk dapat mengetahui apakah siswanya memahami apa yang disampaikan. Pembelajaran aktif dilihat dari penyediaan materi baik secara individual maupun kelompok. Hal ini dimaksudkan untuk membantu siswa bekerja dengan kemampuan sendiri.

4. Pembelajaran aktif dilihat dari kebebasan dalam memilih kegiatan. Siswa hendaknya dibebaskan untuk memilih kegiatan yang mereka inginkan sesuai daya kemampuan mereka masing-masing.

5. Dengan pemberlakuan system belajar aktif

Hendaknya pelajar mempunyai pemikiran aktif dalam proses pembelajaran yaitu aktif dalam mengasah dan mencari pengetahuan (teori sain kognitif) yang melibatkan persepsi, minat, kreativitas, ingatan, penyelesaian masalah, pemikiran penggunaan bahasa, dengan tujuan siswa berupaya memproses pesan dengan system struktur pengetahuan dan kecerdasan.

\section{Karakteristik Pembelajaran Aktif}

Terdapat beberapa karakteristik pembelajaran yang efektif antara lain:

${ }^{26}$ Uzer Usman, Upaya Optimalisasi Kegiatan Belajar Mengajar, Bandung: PT. Remaja Rosda Karya, 2000, hlm 87.

62 MAGISTRA - Volume 10 Nomor 1 Juni 2019 
a. Belajar secara aktif baik mental maupun fisik. Aktif secara mental ditunjukkan dengan mengembangkan kemampuan intelektualnya, kemampuan berfikir kritis. Secara fisik, misalnya menyusun intisari pelajaran, membuat peta dan lain-lain.

b. Metode yang bervariasi, sehingga mudah menarik perhatian siswa dan kelas menjadi hidup.

c. Motivasi Pendidik terhadap pembelajaran di kelas.

d. Suasana demokratis di sekolah, yakni dengan menciptakan lingkungan yang saling menghormati, dapat mengerti kebutuhan siswa, tenggang rasa, memberi kesempatan kepada siswa untuk belajar mandiri, menghargai pendapat orang lain.

e. Pelajaran di sekolah perlu dihubungkan dengan kehidupan nyata.

f. Interaksi belajar yang kondusif, dengan memberikan kebebasan untuk mencari sendiri, sehingga menumbuhkan rasa tanggung jawab yang besar pada pekerjaannya dan lebih percaya diri sehingga anak tidak menggantungkan pada diri orang lain.

g. Pemberian remedial dan diagnosa pada kesulitan belajar yang muncul, mencari faktor penyebab dan memberikan pengajaran remedial sebagai perbaikan, jika diperlukan. ${ }^{27}$

\section{Strategi pembelajaran aktif}

a. Mengidentifikasi serta menetapkan spesipikasi dan kualifikasi perubahan tingkah laku dan kepribadian anak didik sebagaimana yang diharapkan.

b. Memilih sistem pendekatan belajar mengajar berdasarkan aspirasi dan pandangan hidup masyarakat.

c. Memilih dan menetapkan prosedur, metode, dan teknik belajar mengajar yang dianggap paling tepat dan efektif sehingga dapat dijadikan pegangan oleh guru dalam menunaikan kegiatan mengajarnya.

${ }^{27}$ Oemar Hamalik, Kurikulum dan Pembelajaran, Jakarta: PT.Bumi Aksara, 2002, hlm 56. 63 MAGISTRA - Volume 10 Nomor 1 Juni 2019 
d. Menetapkan nama-nama dan batas minimal keberhasilan atau criteria serta standar keberhasilan sehingga dapat dijadikan pedoman. Dalam melakukan evaluasi hasil belajar mengajar yang selanjutnya akan dijadikan umpan balik buat penyempurnaan sistem instruksional yang bersangkutan secara keseluruhan. $^{28}$

\section{Langkah-langkah dalam pembelajaran aktif}

a. Seorang guru harus memilki kemampuan yang lebih selain kemampuan secara teknikal.

b. Memahami bagaimana cara belajar siswa.

c. Pencerminan kemampuan guru itu sendiri secara optimal berasaskan inovasi pengajaran dan pengalaman.

d. Adakah perubahan "concept of knowledge" kita, baik itu proses pembelajaran ataupun peranan guru itu sendiri sesuai dengan apa yang diinginkan untuk pencapaian tujuan dalam proses pembelajaran aktif.

e. Perkenalkan cara belajar baru dan dapat menarik perhatian siswa agar lebih berminat terhadap apa yang guru ajarkan. ${ }^{29}$

Madrasah merupakan lembaga pendidikan yang bercorak keagamaan. Posisi ini menjadi strategis dari sisi budaya di mana karakter keislaman dapat dibangun secara moderat. Madrasah juga strategis dari sisi politis di mana eksistensinya dapat dijadikan sebagai parameter kekuatan Islam. Urgensi madrasah ini dalam tataran yang lebih makro dapat dilihat sebagai representasi wajah dan masa depan Islam Indonesia. Madrasah Ibtidaiyah yang kedudukannya setara dengan Sekolah Dasar (SD) di Departemen Pendidikan Nasional dianggap sebagai satu jenjang pendidikan formal yang paling penting dalam perkembangan setiap individu. Jenjang pendidikan ini mengajarkan tentang dasar-dasar ilmu pengetahuan, seperti membaca, menulis, dan berhitung serta menanamkan dasar-

\footnotetext{
28 Nur Rusini, http://almunawar.nur.blogspot.com/2012/10/strategi-pembelajaran aktif_22.html

${ }^{29}$ Kamaludin Ahmad, Teori Pembelajaran Aktif, Malaysis:MPTI, Januari 2001, hlm 63 - 64
}

64 MAGISTRA - Volume 10 Nomor 1 Juni 2019 
dasar nilai moral kepada setiap anak serta memahami perkembangan psikis anak dalam proses pembelajaran di dalam kelas. Psikologi secara umum mempelajari gejala-gejala kejiwaan manusia yang berkaitan dengan kognisi, emosi, dan konasi. Gejala tersebut secara umum memiliki ciri-ciri yang hampir sama pada diri manusia dewasa, normal, dan beradab. Dengan demikian ketiga gejala pokok tersebut dapat diamati melalui sikap dan perilaku manusia. Namun terkadang ada diantara pernyataan dalam aktivitas yang tampak itu merupakan gejala campuran, sehingga para ahli psikologi menambahnya menjadi empat gejala utama yang dipelajari psikologi, yaitu kognisi, emosi, kognisi dan gejala campuran. Adapun yang termasuk gejala campuran ini seperti intelegensi, kelelahan maupun sugesti. ${ }^{30}$

Proses pengembangan dunia madrasah dalam hal ini Madrasah Ibtidaiyah (MI) selain menjadi tanggung jawab internal madrasah, juga harus didukung oleh perhatian yang serius dari proses pembangunan pemerintah. Meningkatkan dan mengembangkan peran serta madrasah dalam proses pembelajaran merupakan langkah strategis dalam membangun masyarakat, daerah, bangsa, dan Negara, namun aspek pembelajarannya yang berkaitan minat dan motivasi peserta didik.

Psikologi belajar bertujuan memberikan solusi atau perbaikan atas masalah yang dihadapi murid dalam belajar, sehingga murid tidak kesulitan dalam menerima transfer ilmu dari pendidik dan melakukan pembelajaran dengan menyenangkan. ${ }^{31}$ Dengan demikian dapat dikatakan bahwa pembelajaran aktif adalah proses keterlibatan intelektual dan aspek emosional peserta didik dalam proses belajar mengajar yang dapat memungkinkan terjadinya: ${ }^{32}$

\footnotetext{
${ }^{30}$ Jalaluddin, Psikologi Agama, Raja Grafindo Persada: Jakarta, 2010, hlm 7

${ }^{31}$ Padjrin Dha Niess.Teori Psikologi Belajar dan Aplikasinya dalam Pendidikan, 2011

${ }^{32}$ Syafrudin Nurdin dan M. Basyiruddin Usman, Guru Profesional dan Implementasi Kurikulum, Ciputat Press, Jakarta, 2002, hlm 119.
}

65 MAGISTRA - Volume 10 Nomor 1 Juni 2019 
a. Proses asimilasi dan akomodasi dalam pencapaian pengetahuan.

b. Proses perbuatan serta pengalaman langsung terhadap umpan balik dalam pembentukan keterampilan.

c. Proses penghayatan serta internalisasi nilai-nilai dalam rangka pembentukan nilai dan sikap.

Pembelajaran aktif mendorong peserta didik menggerakkan segala daya upaya yang berkaitan aktifitas belajar pesert didik. Hakikat pembelajaran adalah proses komunikasi transaksional antara pendidik dan siswa di mana dalam proses tersebut bersifat timbal balik. Komunikasi transaksional adalah bentuk komunikasi yang dapat diterima, dipahami, dan disepakati oleh pihak-pihak yang terkait dalam proses pembelajaran. Landasan psikologis pembelajaran aktif banyak faktor yang yang termasuk aspek psikologis yang dapat mempengaruhi kuantitas serta kualitas hasil pembelajaran peserta didik. Faktor-faktor mental peserta didik yang pada umumnya dipandang lebih esensial itu adalah sebagai berikut $^{33}$ :

1. Tingkat kecerdasan atau intelegensi siswa

2. Sikap siswa

3. Bakat siswa

4. Minat siswa

5. Motivasi siswa.

Dampak psikologi belajar dalam pembelajaran aktif di Madrasah Ibtidaiyah mempunyai kaitan erat dalam proses belajar mengajar di dalam kelas. Peserta didik mengeksplorasi kegiatan belajar dengan aktif namun menyenangkan sehingga melahirkan tingkah laku yang mendidik dan di sadari. Fungsi psikologis tentu saja mempengaruhi belajar seseorang. Berarti belajar bukanlah berdiri sendiri, terlepas dari faktor lain seperti faktor luar dan faktor dari dalam. Faktor psikologis sebagai faktor dari dalam tentu saja merupakan hal

\footnotetext{
${ }^{33}$ https://ikhsanaira.wordpress.com/2016/05/30/definisi-par-dan-contoh-laporan-penelitianpar/ diunduh 11/7/2018
} 
yang utama dalam menentukan intensitas belajar seorang anak. Minat, kecerdasan, bakat, motivasi, dan kemampuan-kemampuan kognitif adalah faktorfaktor psikologis yang utama mempengaruhi proses dan hasil belajar peserta didik. Motivasi adalah kondisi psikologis yang mendorong seseorang untuk melakukan sesuatu. Jadi motivasi untuk belajar adalah kondisi psikologis yang mendorong seorang untuk belajar. Penemuan-penemuan penelitian menunjukan bahwa hasil belajar pada umumnya meningkat jika motivasi untuk belajar bertambah.

Kaitan psikologi belajar dan pembelajaran aktif pendidik hendaknya selalu berpegang pada asas-asas mengajar sebagai berikut: ${ }^{.34}$

a. Mengajar sepatutnya mempertimbangkan pengalaman belajar (peserta didik) sebelumnya.

b. Proses pengajaran dimulai bila peserta didik dalam keadaan siap untuk melakukan kegiatan belajar.

c. Bahan pelajaran seharusnya menarik minat peserta didik untuk mempelajarinya.

d. Dalam melaksanakan pengajaran, pendidik seharusnya berusaha agar peserta didik terdorong untuk melakukan kegiatan belajar.

e. Proses pengajaran sepatutnya memperhatikan perbedaan-perbedaan individual yang dimiliki oleh masing-masing peserta didik.

f. Pengajaran sepatutnya mengantarkan peserta didik untuk melakukan proses belajar secara aktif.

b. Pelaksanaan pembelajaran sepatutnya berpegang pada prinsip-prinsip pencapaian hasil belajar secara psikologis, yaitu belajar dilakukan secara bertahap dan meningkat:

1) Dari bahan-bahan yang bersifat konkrit menuju ke bahan yang bersifat sederhana meningkat kepada bahan-bahan yang makin rumit atau sulit.

${ }^{34}$ Mulyani Sumantri, Strategi Belajar Mengajar, Maulana, Bandung, 2001, hlm 114.

67 MAGISTRA - Volume 10 Nomor 1 Juni 2019 
2) Dari bahan-bahan yang bersifat konkrit dibawa menuju ke bahanyang bersifat, seperti konsep, ide atau simbol.

3) Dari bahan-bahan yang bersifat umum meningkat ke bahan yang bersifat analisis, dengan kajian yang lebih rumit.

4) Didasarkan penggunaan penalaran, baik induktif (mulai dari mencari fakta dan mengambil kesimpulannya), maupun deduktif (mulai dengan rumusan konsep, kemudian mengujinya berdasarkan fakta yang dialami).

\section{SIMPULAN}

Berdasarkan hasil penelitian dan pembahasannya maka dapat ditarik beberapa simpulan penelitian sebagai berikut:

1. Gambaran kondisi nyata pelaksanaan pembelajaran aktif menunjukkan bahwa pada dasarnya telah terprogram namun pelaksanaannya sering kali tidak sesuai dengan rencana, karena dilaksanakan secara insidental, yaitu dilaksanakan hanya ketika dibutuhkan saja serta bersifat konvensional, yaitu hanya dengan diskusi tanpa mempertimbangkan keikutsertaan peserta diidk secara langsung.

2. Ditemukan dampak positif secara psikologis dalam proses belajar peserta didik ketika pelaksanaan pembelajaran aktif dilakukan.

3. Keterbatasan penelitian ini telah dilaksanakan secara maksimal, akan tetapi masih memiliki keterbatasan antara lain, kelompok eksperimen penelitian juga sebagai kelompok kontrol dalam penelitian ini.

4. Implikasi terhadap hasil-hasil penelitian adalah pelaksanaan pembelajaran aktif sangat memberikan kontribusi yang baik bagi peserta didik dan pendidik, sehingga pada akhirnya dibutuhkan oleh banyak peserta didik di setiap jenjang pendidikan. Pendidik dapat secara intensif menerapkan pembelajaran aktif dan melihat hasil positif dalam psikologi belajar peserta didik. 


\section{DAFTAR PUSTAKA}

Afandi, Agus dkk, Modul Participatory Action Reseacrh (PAR) (IAIN Sunan Ampel Surabaya: Lembaga Pengabdian Masyarakat (LPM), 2013.

Bahri Djamarah, Saiful, Psikologi Belajar, Rineka Cipta: Jakarta, 2008.

Dalvin, Upaya Meningkatkan Keaktifan Belajar Siswa dalam Pembelajaran Agama dengan Menggunakan Metode Belajar Aktif Tipe Quiz Tea, Jurnal Guru, 2006.

Danim, Sudarwan, Menjadi Peneliti Kualitatif, Bandung: CV Pustaka Setia, 2002.

Dha Niess, Padjrin, Teori Psikologi Belajar dan Aplikasinya dalam Pendidikan, 2011.

Fakih, Mansour, Menggeser konsepsi gender dan transformasi sosial, Yogyakarta :Pustaka Pelajar, 2007.

Hamalik, Oemar, Perencanaan Pengajaran Melalui Pendekatan Sistem, Jakarta: Bumi Aksara, 2002.

Http://nurwahyudi.blogspot.com/2010/11/pengembangan pembahasapendidikan.html. diunduh 15/7/2018.

Http://padjrindhaniess.blogspot.com/2011/10/psikologibelajar.htm.diunduh19/7/2018

Jalaluddin, Psikologi Agama, Jakarta: Rajagrafindo Persada, 2010.

Khodijah, Nyayu, Psikologi Belajar, Rafah Press: Palembang, 2006.

Nasution, Noehi, Materi Pokok Psikologi Pendidikan, Jakarta: direktorat, 1998.

Nurdin, Syafrudin dan M. Basyiruddin Usman, Guru Profesional dan Implementasi Kurikulum, Ciputat Press, Jakarta, 2002.

Prastowo, Andi, Memahami Metode-Metode Penelitian.Yogjakarta: ArRuzz Media, 2011.

P. Reason,. and H. Bradbury, The Sage Handbook of Action Research: Participative Inquiry and Practice. California: Sage, 2008. 
Ramayulis, Psikologi Agama, Kalam Mulia: Jakarta, 2007.

Sagala, Syaiful, Konsep dan Makna Pembelajaran, Bandung: Alfabeta, 2003.

Soegeng Ysh., A.Y, Pengembangan Sistem Pembelajaran, Semarang: IKIP PGRI Semarang Press, 2012.

Sugiono, Prosedur Penelitian, Yogyakarta: Aditya Media, 2010

Sumantri, Mulyani, Strategi Belajar Mengajar, Bandung: Maulana. 2001.

Suprayogo, Imam dan Tobrani, Metodologi Penelitian, Bandung: PT Remaja Rosdakarya, 2003.

Syah, Muhibbin, 2013. Psikologi Belajar. Jakarta: Rajawali Pers, 2013.

Triana Primasari, Ria dan Rohmalina Wahab, dan Elhefni, Kecerdasan Emosional dan Belajar, Palembang: Grafiko Telindo Press, 2012.

Undang-Undang Nomor 14 Tahun 2005, Tentang Guru dan Dosen, Jakarta: Depdiknas.

Undang-Undang Nomor 20 Tahun 2003, Tentang Sistem Pendidikan Nasional, Jakarta: Depdik.

Ahmad, Kamaludin, 2001.Teori Pembelajaran Aktif, Malaysis: Rosda Karya, 2001

Wahab, Rohmalina, Psikologi Belajar, Palembang: Grafiko Telindo Press, 2014.

Wardhani dan Kuswaya Wihardit, Penelitian Tindakan Kelas, Jakarta: Universitas Terbuka, 2007. 